\title{
Contact with Biological Parents for Children in Residental Care: A Vietnam Study
}

\author{
Nguyen Ba Dat ${ }^{1}$, Nguyen Van Luot ${ }^{1}$, Nguyen Ha Thanh ${ }^{2}$ \\ ${ }^{1}$ Faculty of Psychology, University of Social Sciences and Humanities, Vietnam National University in Hanoi, \\ Hanoi, Vietnam \\ ${ }^{2}$ FPT University, Hanoi, Vietnam \\ Email: nbdat@vnu.edu.vn, luotnv@vnu.edu.vn, thanhnh29@fe.edu.vn
}

How to cite this paper: Ba Dat, N., Van Luot, N. and Ha Thanh, N. (2018) Contact with Biological Parents for Children in Residental Care: A Vietnam Study. Open Journal of Social Sciences, 6, 277-292. https://doi.org/10.4236/jss.2018.611021

Received: October 4, 2018

Accepted: November 23, 2018

Published: November 26, 2018

Copyright (c) 2018 by authors and Scientific Research Publishing Inc. This work is licensed under the Creative Commons Attribution International License (CC BY 4.0).

http://creativecommons.org/licenses/by/4.0/

(c) (i) Open Access

\begin{abstract}
Children living in residential care have a degree of separation from their parents and other family members. Based on attachment theory, this study was conducted to analyze the contact between these children and their biological parents, and the factors affecting this contact. The sample included 382 children (orphans, abandoned or helpless children, children whose parents are deprived of custody or are unable to raise a child) living in residential centers located in North, Central and South of Vietnam. Data were obtained by semi-structured interviews. The results showed that, on average, children contact their parents and family members once a month. In addition, variables such as family image in children's mind and joyfulness when meeting parents are the best predictors of contact between children and parents, family members. The contact between children and parents is arguably considered as a form of consolidation and maintenance of emotional relationship.
\end{abstract}

\section{Keywords}

Contact, Children, Parents, Family, Residential Care

\section{Introduction}

The contact between the children in out-of-home care and their parents is targeted communication, either directly or indirectly [1] [2]. Children and adolescents are also exposed to those who play an important role in their lives such as siblings, paternal and maternal grandparents, aunts, uncles. This contact takes place directly or indirectly. For example, parents could come to see children, send theme letters, messages, gifts, phone or chat with them, and vice versa. Direct contact or indirect one through letters or messages is gradually replaced by 
online conversations via Skype [3].

In the Vietnamese context, according to Children's Law, Children are people under 16 years old [4]. According to the International Convention on the Rights of the Child (1989), children are people under 18 years old [5]. In the scope of this article, children are understood to be under 18 years old. Children are taken care of outside the family in the following forms: 1) guardianship-Children live with grandparents or maternal grandparents, siblings, aunts, or uncles, take care of children when their parents died or go to work far away, imprisonment, custody of children; 2) children living in Social Protection Centers; 3) in charitable house founded by individuals and/or charities; 4) in Religious establishments (pagodas or church facilities; 5) children being adopted domestically or overseas; 6) Children in foster care. According to the Unicef report on Vietnamese Children in 2010, Vietnam has about 372 social welfare establishments in 2005 called Social Protection Centers. These establishments are under the management of the Ministry of Labor, Invalids and Social Affairs. An estimated 20,000 children are cared for in public and private settings, of which around 15,000 children are cared for in public facilities, and 5000 are taken care of by private ones. Among the children living in residential care facilities, more than 10,000 were abandoned children, 5000 were orphans and more than 2000 were children with disabilities. At present, there is no accurate data on the number, age, sex, ethnicity, needs and causes of being placed in residential care settings [6].

The current study, the contact between children in residential care and their parents and family members is a quite appealing subject, drawing much attention from a number of researchers. Some authors tend to point out the benefits and significance of visits of parents and family members, and their communication with children. Parent visiting is an important factor in maintaining a close bond between parents and children [7]. Frequent contact with parents is a protective factor that helps children prevent the internalizing and externalizing problems [8]. High quality parental and family visits help children reunite with the family in the future and create a solid family position for them [9]. Except for cases of severe child abuse, parents are often encouraged to maintain close contact with children when they are separated from their families into residential care settings. Parent-child interaction is considered important because it helps maintain family cultural identity, ensure children's well-being, and maintain the bonding between children and parents [10].

There are a number of evidences showing the positive effects associated with the contact between parents, family members and children in residential care, however, these evidences are relatively weak because they are results from studies which were conducted in small-scale, with qualitative design, or by collecting data in separate locations with no comparison and control [3]. In addition, there are conflicting evidences indicating that contact with parents and family members bring disadvantages to children. Because some children are not in contact with their parents by appointment, parents do not visit the children, or 
many visits of parents are of low quality. As a result, children do not feel the warmth from their parents [11]. Regular parental visits lead to conflicts between children, caregivers and parents. These conflicts are considered as a risk factor for children with emotional and behavioral difficulties [12]. Parental visits and support may cause emotional and behavioral problems of children living in social protection centers [13]. As many as $34 \%$ of foster parents believe that family visits are not good for children and $49 \%$ foster parents find that children have emotional and behavioral problems related to the interaction with birth parents and family members [14].

In spite of the unfavorable evidence for the contact between children in residential care and their parents, family members, the need to meet, contact and interact with parents is still there in children. They are longing to meet parents. Most of the children in residential care want to contact their parents, and even if the communication is not very pleasant, they still like and plan to return to live with their parents [9]. The International Convention on the Rights of the Child recognizes that every child has the right to live with his or her parents and/or to contact his or her parents unless the contact is harmful to the development of the child [5].

In order to ensure the contact to be most beneficial to children, and to contribute to the children's right to live and/or to contact their parents, the factors involved in the interaction between children in residential care and their parents, family members have been studied and discussed. John (2010) examined the criteria for determining whether or not the parents met the child, the frequency of the encounter and the quality of each encounter [15]. Atwool (2013) explores the views of children and adolescents, caregivers, social workers on the interaction between children and their parents and relatives. The author found that the relationship between children and their parents was related to children's age, ability, developmental and cultural characteristics, and the indications given by the care settings [16]. Helen et al., (2013) emphasized the importance of caregivers to parent-child contact [17]. Salveron et al., (2009) proposed a group-based approach to working with biological parents whose pre-school-aged children have been placed in care [10]. Mota \& Matos, (2015) studied the effects of self-concept and resilience in adolescents under residential care [18].

Studies on children living in residential care in Vietnam indicated that children by and large have to live for long period of time in the residential care setting, from birth to adulthood [6]. Children living in residential care facilities tend to depend on the person responsible for giving care [19]. Orphaned children living in social protection centers have higher rates of psychological disturbances in terms of emotion and behavior than children living with their families [20]. The contact between children in residential care and their parents, family members is considered as an important activity in the care of these children [21]. However, hitherto, there is no study investigating the status quo of the contact between children and their parents, family members and its impacts on child 
care in residential care, and the family reunification after leaving there.

As can be seen from literature review, the main purpose of the interaction between children in residential care and their parents is to consolidate and maintain the relationship between them and to create prerequisites for the children's reintegration with family later. The research results on this topic are controversial. A number of studies suggest that contact between children in residential care and parents, family members is beneficial, while some authors possess a contrasting perspective. They have argued that contact with parents is harmful, causing emotional and behavioral problems in children. Some in-depth studies investigate the factors involved in decision making, the support and supervision of contact between children and parents and family members. Another limitation related to research on this topic is the lack of empirical or controlled experiments. Consequently, statements or conclusions about the positive or negative impact of the contact on the development of the child are not sufficiently convincing. In addition, the source of information is primarily from caregivers, social workers or parents, while there are not many surveys investigating the opinion of children living in residential care facilities.

Therefore, our understanding of the contact between children in residential care and their parents, family members is limited, especially in Vietnam. This is an important issue related to ensuring the right of children to live and to be in touch with their parents and families. It is also a developmental issue related to the developmental environment of the child, the relationship of the child to others, the developmental aspects of the child, such as the development of identity and the capacity for social adaptation of the child. Given the significance of the issue and the gaps in research on this topic, further studies on this topic need to be carried out. Thus, this study deals with the contact between children in residential care and their parents and family members in Vietnam.

This study is based on attachment theory and discusses the importance of the quality of affect. The attachment theory of Bowl by (1988) suggests that the relationship between children and parents (or caregiver) during the early years of life plays an important role in the development of the children's emotional procedure. Children stick with their parents or caregivers in four types of attachment, namely secure, avoidant, ambivalent and disorganized attachment. Depending on the type of attachment to parents and caregivers, children will react differently to difficult situations and challenges in life during the adulthood. If children have a secure attachment to their parents or caregivers in the early years of life, they tend to be in touch with and close to their parents and caregivers when they are distressed in adulthood. In the context of separation from the family, the connection between children and parents and family members is interrupted, making the feeling of rejection appear in the mind of the child [18].

Based on the attachment theory and child interview results, this study describes the current situation, factors predicting the contact between parents, family members and children in residential care. We hypothesized that 1) some 
children in residential care do not meet and interact with their parents and family members; 2) on average, every month, children come in contact with their parents and family members in different forms; 3) children living in charitable houses come in contact with parents and family members more often than children in other residential care; 4) Family image in children's mind, number of years children live with their parents, positive emotions each time they come in contact with their parents, and the intimate relationship between children and their parents, as well as other family members, can predict the contact between children and parents and family members.

\section{Method}

\subsection{Sample}

The forms of children residential care in Viet Nam are quite diverse. To ensure the representative sample of the survey, cluster sampling was used in this study. Unit of sampling is a form of child residential care. Step 1, research team listed all forms of child residential care now available in Vietnam. The results show that, there are four popular forms of child residential care currently available: SOS Children's Village, social protection center, charitable houses, religious establishment. Step 2, lists the names and addresses of centralized child residential care facilities, categorize the facilities according to each child residential care model. Step 3 randomly selects a number of facilities under each model. As a result, the research team selected a SOS children's village, two social protection center, five charitable houses, a child care facility of one pagoda. The selected establishments have public or private. Total number of surveyed samples include 382 children aged 6 to 18 years ( 269 children contact with biological parents, 113 children non-contact).The study samples are described in detail in Table 1.

\subsection{Measures}

Data was collected from children in residential care through face-to-face interviews based on a structured questionnaire consisting of 16 questions. This questionnaire was developed by the research team as follows: Step 1, based on attachment theory, provides a number of topics related to contact between a child and a parent and family members. For example, when children are separated from their parents, caregivers before they are separated from their families, years of living with their parents, family circumstances, etc. Step 2, the research team conducted group discussions with children and caregivers. Step 3, the research team referred the results of the group discussion to stick theory, which provided a semi-structured questionnaire consisting of 16 sentences. Questions are open or closed, for example, question 4 was about the circumstances of the children's lives before being admitted to the residential care, "Do you remember people you lived with before living in this center?" The answers were "remember" or "do not remember". For those who remembered, the next question would be "Who do you live with? From which year to which year?" This question has the 
Table 1. Description of surveyed samples.

\begin{tabular}{ccccc}
\hline Criteria & Classification & $\begin{array}{c}\text { Contact } \\
(\mathrm{N}=269)\end{array}$ & $\begin{array}{c}\text { Non-contact } \\
(\mathrm{N}=113)\end{array}$ & $\begin{array}{c}\text { Total } \\
(\mathrm{N}=382)\end{array}$ \\
\hline \multirow{2}{*}{ Sex } & Male & $52.4 \%(\mathrm{n}=141)$ & $46.9 \%(\mathrm{n}=53)$ & $50.8 \%(\mathrm{n}=194)$ \\
& Female & $47.6 \%(\mathrm{n}=128)$ & $53.1 \% \quad(\mathrm{n}=60)$ & $49.2 \%(\mathrm{n}=188)$ \\
& From 6 to 11 years old & $28.4 \%(\mathrm{n}=79)$ & $23.9 \%(\mathrm{n}=27)$ & $27.7 \%(\mathrm{n}=106)$ \\
Age & From 12 to 15 years old & $47.6 \%(\mathrm{n}=128)$ & $44.2 \%(\mathrm{n}=50)$ & $46.6 \%(\mathrm{n}=178)$ \\
& From 16 to 18 years old & $23.0 \%(\mathrm{n}=62)$ & $31.9 \%(\mathrm{n}=36)$ & $25.7 \%(\mathrm{n}=98)$ \\
& Mean (SD) & $13.09(2.86)$ & $13.61(3.16)$ & $13.24(2.95)$ \\
& SOS Children's Village & $30.1 \%(\mathrm{n}=81)$ & $31.9 \%(\mathrm{n}=36)$ & $30.6 \%(\mathrm{n}=117)$ \\
Care & Social Protection Centre & $27.9 \%(\mathrm{n}=75)$ & $22.1 \%(\mathrm{n}=25)$ & $26.2 \%(\mathrm{n}=100)$ \\
model & Charitable house & $36.4 \%(\mathrm{n}=98)$ & $23.9 \%(\mathrm{n}=27)$ & $32.7 \%(\mathrm{n}=125)$ \\
& Pagoda & $5.6 \%(\mathrm{n}=15)$ & $22.1 \%(\mathrm{n}=25)$ & $10.5 \%(\mathrm{n}=40)$
\end{tabular}

following options: children live with both parents from year X to year $\mathrm{Y}$, children live with their mothers from year X to year $\mathrm{Y}$, children live with their fathers from year $\mathrm{X}$ to year $\mathrm{Y}$, children live with grandparents from year $\mathrm{X}$ to year $\mathrm{Y}$, children live in another center from from year $\mathrm{X}$ to year $\mathrm{Y}$. Or question 3 "How long have you been in this center?" This question had the following options: "Less than 6 months", "from 6 months to less than 1 year", "from 1 to less than 2 years", "from 2 to less than 5 years", and "over 5 years", question 11 was about the contact between children and their parents, as well as other family members. This question had the answers: never come in contact or interaction, once a month, three times a month, or more than three times a month. Some questions are designed in the form of a likert scale. For example, question 14 asks the child's level of satisfaction about living in residential care. The answers to this question are: 0 ) completely dissatisfied, 1) less satisfied, 2) heart, 3) very satisfied.

\subsection{Procedure}

Data was collected at nine residential cares, in the North, Central and South of Vietnam. The data of this article is a part of a research project on the effectiveness of group counseling for children with psychological difficulties living in social protection facilities. The research guideline has been reviewed and approved by the Research Ethics Council of the University of Social Sciences and Humanities, Vietnam National University in Hanoi. The research purposes and research methodology of the project was introduced and received the agreement of nine residential care managers. The principles of confidentiality, anonymity, volunteer participation have been communicated to children and caregivers responding to the questionnaire. One hundred percent of children agreed to participate in the study voluntarily after disseminating ethical principles, purpose and method of answering questions. The survey was carried out from April to October in 2017. 


\subsection{Data Analysis}

The contact between parents, relatives and children in residential care is a form of maintenance and reinforcement of children's relationship with his or her parents and family members [7]. Things that a child remembers about his or her family, such as his hometown, family address, and caregiver before he or she lives in residential care are all the things that make a family look like in his or her mind. It motivates the child to seek out and relate to his or her parents and family members.

The compute variable was used to generate a variable of family image in children's mind by taking the sum of the answers of questions related to children remember their hometown, remember caregivers before living in residential care and children remember and keep their parents' or families' address. The family image had $(M=2.00, S D=0.89)$ the highest point of 3 and the lowest point of 0 . The descriptive analysis was used to compare mean of the contact between children and parents, family members, between groups of children and to indicate the correlation between the variables. To predict the impacts of independent variables on the contact between children and parents, linear regression testing with enter method models was used. The general linear regression model is as follows:

$$
Y_{c}=\beta 0+\beta 1(X 1)+\beta 2(X 2)+\cdots+\beta k(X k)
$$

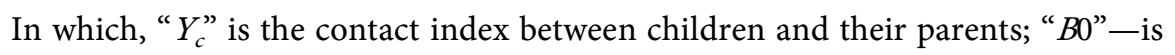
the constant; " $B 1$ "- is the regression coefficient; " $X 1$ " is the independent variable introduced into the model; " $k$ " is the number of independent variables of the model. We construct linear regression models with four variables, namely 1, 2, 3, 4. Model 1 has the independent variable representing the family image in the mind of children. Model 2 includes the variables from model 1 and another independent variable that is the number of years living with parent and family members. Model 3 includes independent variables from model 2 and the independent variable indicating the emotions of children in contact with parents and family members. Model 4 includes variables from model 3 and independent variables that represents the relationship between children and parents and family members. All analyses were performed by using IBM SPSS Statistics for Windows, Version 21.0.

\section{Result}

\subsection{Descriptive Statistics}

The findings showed that $113(29.6 \%)$ children never come in contact with parents and family members; 141 (36.9\%) children contact their parents and family members once a month; 31 (8.1\%) children contact their parents and family members three times a month, and $97(25.4 \%)$ children contact parents and family members more than three times a month; $(\mathrm{M}=1.29$; $\mathrm{SD}=1.14)$.

Independent samples $\mathrm{T}$-Test conducted to examine relationship between children's gender on the contact between them and their parents, family mem- 
bers, showed that there was no differences between the two groups of gender. The contact with parents and family members of males $(\mathrm{M}=1.30$; $\mathrm{SD}=1.11)$; and females $(M=1.28 ; S D=1.17)$. The relationship of the child's gender $t(380)$ $=-0.18, p=0.85)$ on their contact with parents and family members was not statistically significant. A One-way ANOVA analysis was carried out to test the relationship of children's age, care giving model and caregiver (before they came in residential care) on children's contact with parents, family members. The results are presented in Table 2 . The contact with parents and family members of different age groups was not different. Specifically, children aged from 6 to 11 years old $\mathrm{M}=1.17, \mathrm{SD}=1.01$; children aged from 12 to 15 years: $\mathrm{M}=1.4, \mathrm{SD}=$ 1.19; children aged from 16 to 18 years $M=1.21, S D=1.18$. The influence of the children's age $\mathrm{F}(2,379)=1.6, \mathrm{p}=0.20$, on their contact with parents and family members was not statistically significant.

Comparison of the contact with parents and family members among groups of children from different facilities indicated that the group of children living in a charitable house had the highest level of the contact with parents: $\mathrm{M}=1.68$, SD = 1.20; followed by children living in social protection centers: $\mathrm{M}=1.39, \mathrm{SD}=$ 1.12; children living in the pagoda had the lowest level of contact with their parents and family members: $\mathrm{M}=0.47, \mathrm{SD}=0.75$. The influence of care model: $\mathrm{F}$ $(3,378)=15.0, p=0.00$ to the contact between children and their parents or family members was statistically significant. The results also showed that the last caregiver before children entered residential care affected the contact between children and their parents and family members. Children who did not remember and know about the last caregiver before living in residential care had the lowest number of times of contact with their parents and family members compared to the children who remembered and could be able to talk about their last caregivers. The influence of the last caregiver before children entered residential care on their contact with parents andlor family members: $\mathrm{F}(5,376)=6.98, p=0.00$ was statistically significant.

The correlation, means, and standard deviations of variables are shown in $\mathrm{Ta}$ ble 3. As expected, the contact between children and their parents andlor family members during the time living in residential care had a strong correlation with these variables. The strongest correlation was the one between the contact and the emotions when meeting with parents and family members $(r=0.62)$, followed by the one between the contact with the intimate relationship with parents and family members $(r=0.47)$. There are also positive correlations among variables. In particular, the number of years living with parents and the family image had a positive correlation $(r=0.45)$. Children's emotions and intimate relationships were also positively correlated $(\mathrm{r}=0.52)$.

\subsection{The Influences of Variables on the Contact between Children and Parents and Family Members}

The influences of family image, number of years living with family, emotions when contacting with parents or relatives, intimate relationship between children 
Table 2. Comparison of the contact with parents andlor family members among groups of children.

\begin{tabular}{|c|c|c|c|c|}
\hline \multirow[t]{2}{*}{ Criteria } & \multirow[t]{2}{*}{ Groups } & \multirow[t]{2}{*}{$\mathrm{N}$} & \multicolumn{2}{|c|}{$\begin{array}{l}\text { The contact between children and their } \\
\text { parents, family members }\end{array}$} \\
\hline & & & Mean (SD) & $\mathrm{t}, \mathrm{F}, p$ \\
\hline \multirow[b]{2}{*}{ Sex } & Male & 194 & $1.30(1.11)$ & \multirow[b]{2}{*}{$\mathrm{t}(380)=-0.18, p=0.85$} \\
\hline & Female & 188 & $1.28(1.17)$ & \\
\hline \multirow{3}{*}{ Age } & From 6 to 11 years old & 106 & $1.17(1.01)$ & \multirow{3}{*}{$\mathrm{F}(2,379)=1.60, p=0.20$} \\
\hline & From 12 to 15 years old & 178 & $1.40(1.19)$ & \\
\hline & From 16 to 18 years old & 98 & $1.21(1.18)$ & \\
\hline \multirow{5}{*}{$\begin{array}{l}\text { Care giving } \\
\text { model }\end{array}$} & SOS Children's Village & 117 & $1.06(1.00)$ & \multirow{5}{*}{$\begin{array}{c}F(3,378)=15.00, p=0.00 \\
(3)>(1), p=0.00 \\
(3)>(2), p=0.04 \\
(3)>(4), p=0.00\end{array}$} \\
\hline & Social Protection Centre & 100 & $1.39(1.12)$ & \\
\hline & Charitable house & 125 & $1.68(1.20)$ & \\
\hline & & & & \\
\hline & Pagoda & 40 & $0.47(0.75)$ & \\
\hline \multirow{8}{*}{$\begin{array}{l}\text { Caregiver } \\
\text { (before they } \\
\text { came in } \\
\text { residential } \\
\text { care) }\end{array}$} & $\begin{array}{l}\text { Children did not } \\
\text { remember }\end{array}$ & 77 & $0.70(0.98)$ & \multirow{8}{*}{$\begin{array}{c}\mathrm{F}(5,376)=6.98, p=0.00 \\
(1)<(2), p=0.00 \\
(1)<(3), p=0.00 \\
(1)<(4), p=0.02 \\
(1)<(5), p=0.00 \\
(1)<(6), p=0.00\end{array}$} \\
\hline & Father and mother & 127 & $1.44(1.13)$ & \\
\hline & Mother & 67 & $1.64(1.20)$ & \\
\hline & Father & 4 & $2.00(0.81)$ & \\
\hline & Parental/maternal & 89 & $1.22(1.05)$ & \\
\hline & grandparents & & & \\
\hline & Other center & 18 & $1.61(1.24)$ & \\
\hline & Total & 382 & $1.29(1.14)$ & \\
\hline
\end{tabular}

Table 3. Correlations between variables, means and standard deviations.

\begin{tabular}{|c|c|c|c|c|c|}
\hline Variables & 1 & 2 & 3 & 4 & 5 \\
\hline 1) Contact with parents and family members & - & & & & \\
\hline 2) Family image in children mind & $0.34^{\star \star}$ & - & & & \\
\hline 3) Number of years living with the family & $0.31^{\star \star}$ & $0.45^{\star *}$ & - & & \\
\hline 4) Emotions when meeting with parents and family members & $0.62^{* *}$ & $0.36^{* *}$ & $0.26^{* *}$ & - & \\
\hline $\begin{array}{l}\text { 5) Intimate relationships between children and parents and } \\
\text { family members }\end{array}$ & $0.47^{\star *}$ & $0.31^{\star *}$ & $0.22^{* *}$ & $0.52^{* *}$ & - \\
\hline M & 1.29 & 2.14 & 5.77 & 2.06 & 2.05 \\
\hline SD & 1.14 & 0.88 & 4.03 & 1.5 & 1.44 \\
\hline Note. $\mathrm{N}=382,{ }^{* *} p<0.01$ & & & & & \\
\hline
\end{tabular}

and parents and family members on the contact are presented in (Table 4). The results show that in the first model, the family image had a significant influence on the contact between children and their parents and family members, predicting $12.5 \%$ of its variance. In model 2 , the effect of family image and number of years living with parents or family members on dependent variables was different: $\mathrm{F}(2,379)=34.43, p=0.001$, with a contribution of $15.4 \%$ of the total 
Table 4. Multiple regression models predicting the contact with biological parents of children in residential care.

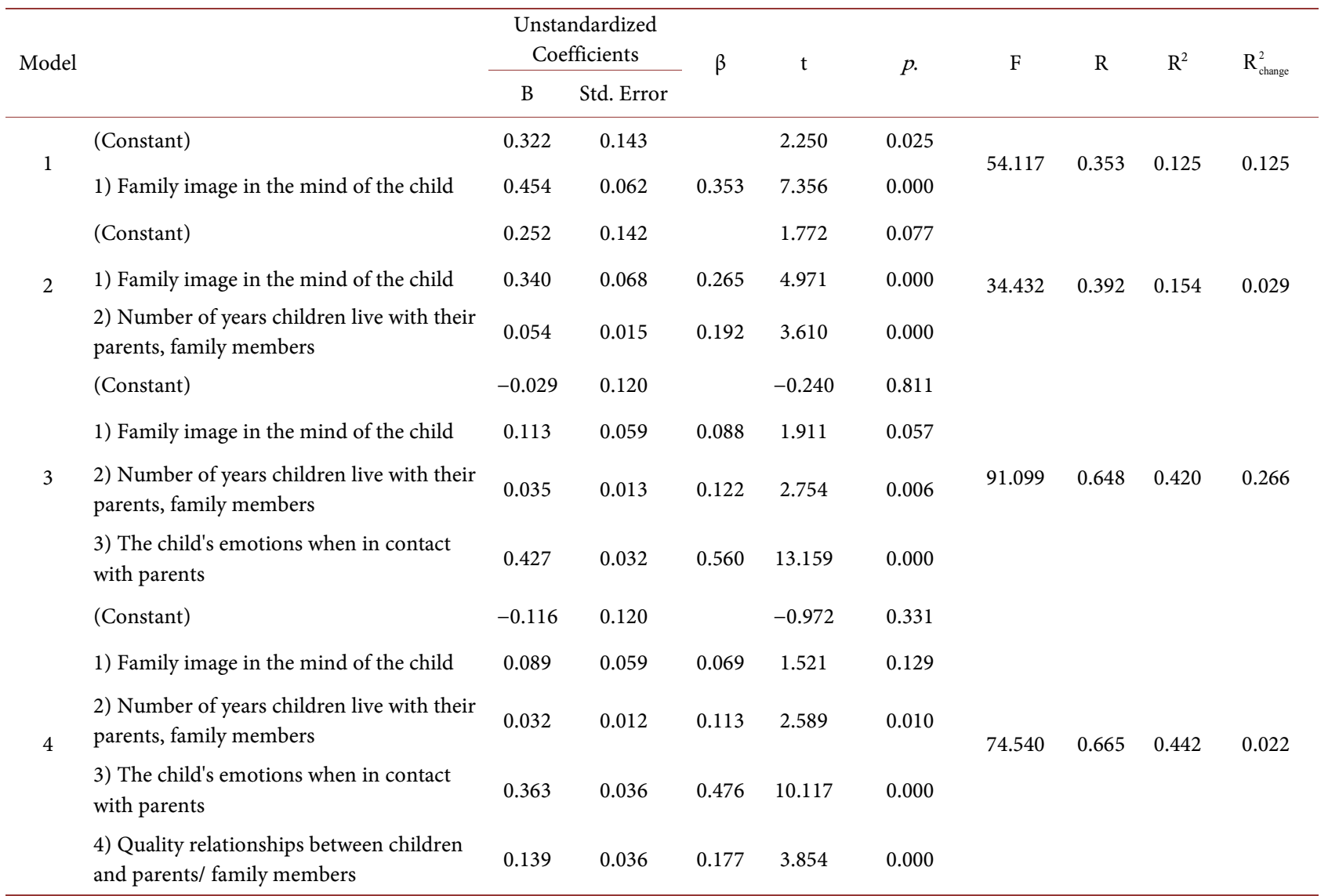

variance $\left(\mathrm{R}^{2}=0.154\right), 2.9 \%$ of variance explained for the model $\left(\mathrm{R}_{\text {change }}^{2}=\right.$ 0.029). According to the analysis of the interaction coefficient between variables in model 2 and the dependent variable, the family image had a close positive coefficient $(\beta=0.26, p=0.00)$. In the third model, the influence of independent variables on the contact between children and their parents or family members was also different: $\mathrm{F}(3,378)=91.09, p=0.001$, with a contribution of $42 \%$ of the total variance $\left(\mathrm{R}^{2}=0.420\right)$, and $26.6 \%$ of variance explained for the model $\left(\mathrm{R}_{\text {change }}^{2}=0.266\right)$. In the third model, the influence of positive emotions of the child when meeting his or her parents or family members on the contact was very clear $(\beta=0.56, p=0.00)$. In model 4 , there was an additional intimate relationship between children and their parents, family members, with a contribution of $44.2 \%$ of total variance $\left(\mathrm{R}^{2}=0.442\right)$, and $2.2 \%$ of variance explained for the model $\left(\mathrm{R}_{\text {change }}^{2}=0.022\right)$. This suggests that the quality of the relationship between children and their parents, family members did not significantly affect the independent variable. The analysis of the interaction coefficient between the contact between children and their parents and quality of the relationship showed significant values $(\beta=0.17, p=0.00)$.

\section{Discussion}

This study examined the contact between parents or family members and child- 
ren in different residential care facilities; and the role of the family image in the mind of children, the number of years children live with their parents, family members, emotions when contacting with parents or family members, and intimate relationship between children and parents, family members. The results were consistent with our expectation. One third of the children reported that they never came in contact with their parents or family members. On average, each month the children contacted their parents, family members about once ( $M$ $=1.29 ; \mathrm{SD}=1.14)$. A recent study found that a large proportion of children were not exposed to parents, and many of whom did not attend parental appointments [11]. There is no consistency when discussing the frequency of the contact between children and their parents [13] and frequent parent-child contact, if it occurs, is weekly. The frequency of the contact also increases as children and parents have experience of controlling negative emotions and behaviors [22]. Decisions related to the frequency of the contact should take into account the state of the relationship between parents and children, children's motive, the ability to meet children's needs, the safety of children, geographic distance, financial situation, or the children's need for parental exposure [3] [23]. In Viet Nam, legal documents related to care giving, protection and education of children in residential care have been issued. Children have the right to keep in touch with their parents or family members. "When being separated from a parent, children are assisted to maintain contact with their father, mother, and family, unless it is inappropriate for the best interests of children" [4]. "While children are living support facilities, social protection institutions, reformatories, detoxification facilities, the parents of children have the responsibility to regularly visit and help them; children support facilities, social protection centers, reformatories and detoxification facilities must create conditions for children to keep in touch with their families and to have access to the services of protection, children's education" [21]. Legal documents generally state that, but no study shows how often the contact between the child and the parent is reasonable. Does this contact need supervision or assistance? In fact, in Viet Nam, contact between a child and a parent or family member is related to the pattern of child care, the origin of the child, the family image in the child's mind, parents, relatives and the quality of the relationship between children and parents, the ability of children and their parents and family members to access and use information technology such as smart phones and social networking sites to get in touch.

The present study's results are consistent with our hypotheses. Children living in charitable houses had the highest number of times of contact with parents, family members, followed by children living in public social protection centers. And children living in the pagodas had the lowest number of times of contact with parents. What makes this difference? Research indicated gender and age were not the factors that made the difference. The first factor is the family circumstances of the children, 68 (54.4\%) children raised in charitable houses were separated from parents because their parents went to work far away, went to jail, were drug addicts, or lost the ability to take care for children. In the circums- 
tances of being separated from their parents, this group of children still had parents to contact or meet. In SOS Children's Village, 68 (58.1\%) children were double orphans, $22(18.8 \%)$ children were paternal or maternal orphans. There are $53(53 \%)$ double orphans, $28(28 \%)$ maternal or paternal orphans in public social protection centers. Due to the fact that these children had no parents to contact, the number of times they were exposed to parents was lower than that of children living in charitable houses. Children living in care giving facilities of pagodas had the lowest number of times of contact with parents and relatives since they were abandoned children; therefore, the pagoda and the children themselves did not know who their parents are. The opportunity for these children to be exposed to their parents and families was lower than that for other groups. Also related to family circumstances, the children's caregiver before they came to live in residential care facilities also had a weak influence on the contact between children and their parents and family members. At charitable houses, $75(60 \%)$ children had lived with their parents, or with their father before they entered there. At pagodas' care giving facility, only 14 (35\%) children had lived with their parents or father or mother or grandparents before entering the pagoda. Up to 23 (57.5\%) children didn't remember who they had lived with before entering the pagoda. Thus, the contact with parents of children living in pagodas was at the lowest level.

The second cause relates to the resources, the care giving models and the management of facilities. In Vietnam, charitable house are built and operated by individuals and organizations with kindness. The government does not provide funding for these facilities. The philosophy of operation of these facilities is that together individuals not contributes a small part to help children in difficult circumstances. With such limited resources, use number of staff in these facilities is relatively small, about 3 to 4 people being responsible for 15 to 20 children. Sometimes employees of charitable houses allow children to stay at their relatives' house 1 to 2 days to save money. These charitable houses are often built right in the neighborhood, welcoming children and youth in the community. Therefore, at the weekend or on a weekday the children could go back to visit their grandparents, aunts, uncles, unless and then return to the facilities. At the public social protection center or SOS children's villages, the funding is either provided by the government or sponsored by International SOS organization, including funds for the return of the child to the family twice a year, on summer vacation and at the Tet holiday. Besides visiting family twice, children could only meet parents and relatives when these people visit children or when children call or chat with them through social networks. The distance from the family to the facilities is quite far. There are families away from the facilities $200 \mathrm{~km}$ and the transportation is relatively difficult. Generally, children will not visit family or parents themselves. They need the support from the centers' staffs or their family members to pick them up to visit the family. At pagodas, the cost of raising children comes from Buddhists' donations, thus pagodas do not have any financial difficulties to support children's life as well as to help them visit their parents 
and relatives. However, pagodas believe that when a child is abandoned or separated from his or her parents, people should help the children become more compassionate by directing them towards the Buddha. Pagodas worry that the contact with parents and relatives is not good for children. Therefore; finding, contacting and meeting parents are not appreciated and implemented. The conception of pagodas is similar to some authors possessing the view that when a child is adopted or sent to an adoptive family, the regular contact with parents or family members will be not good for the development of children and can lead to loyalty conflict [24]. Poor and unattended contact may harm the child, especially in cases where the child has a history of abuse [9]. Exposure to children without a clear plan and purpose is likely to cause conflict between the caregiver and the parents of the child [25].

Based on attachment theory, this study explores the family image within the mind of children, the length of time children live with their parents, the role of the emotional factor of children when contacting parents and relatives, and the quality of the relationship between children and parents in the contact between children and their parents or relatives. These factors play the role that motivating children to interact with their parents and family members. The findings confirm our hypothesis that these variables have the potential to predict $44.2 \%$ of the extent to which children in residential care come in contact with their parents or relatives. This finding clarifies some perspectives that most children will return to live with their parents, especially their mothers, as they mature and leave their care giving facilities [26]. Among these factors, family image had a positive correlation with the contact and predicted $12.5 \%$ of its variance. Family image in the children's mind is the things children remember about their family. In particular, children remember where they was born, where they lived before living in residential care centers, and their families' address. They are factors both motivating and facilitating the children's contact with the family. Family image in the children's mind help children maintain biological relationships and intimate relationships with parents or family members, learn about their roots, and develop their self-identity.

Positive emotions such as joy and happiness of children when they contact with their parents, and family members pay the role, which is motivating children and parents to contact and meet each other. Children's joyfulness and happiness forecast up to $26.6 \%$ of the level of children's contact with their parents and family members. These positive emotions relieve feelings of denial and nostalgia in children and parents when they are separated. Joyfulness and happiness appear when children meet their parents and family members and are both consequences and motivating factors of the contact. In fact, in Vietnam, the life of children in residential care is difficult and lacks of emotions. Children living in charitable houses with limited resources, inadequate meals, and inadequate facilities and equipment have an extremely difficult life. Children living in public social protection facilities are at risk of bullying and abuse. These difficulties motivate children to contact their parents and family members. Children would 
feel excited and happy to be with them.

Limitations. although the findings of our study increase our understanding of the contact between children in residential care and their parents and family members, some limitations of the study should be considered when explaining the results. This is a cross-sectional study that does not offer any explanation of the causal relationship between variables. Due to the fact that the primary research data was collected from children through a semi-structured questionnaire, the data was not compared with other sources of information which may be obtained from caregivers, social workers, or parent.

Future research: Future studies should be designed to assess all factors affecting the interaction between residential care children and their parents and relatives. Factors associated with children and their parents and family members, the operating model of care giving facilities, awareness of caregivers and social workers of contact between children and their parents and family members need to be examined and investigated. Future studies should collect data from different sources in order to achieve a better comparison and verify the results of the study. Finally, future researches will be more valuable when there are control groups and experimental group to verify the impact of contact between children in residential care with parents and family members, on developing capacity for social adaptation, on the forms and the children's ability to reintegrate into their families after leaving residential care. They are gaps in studies on children in residential care in Vietnam.

\section{Conclusion}

Children in residential care have a sense of loss due to separation from parents and relatives. Contact with parents and family members is a form of intervention that maintains and strengthens parent-child relationship. Based on attachment theory and the data collected primarily from children in residential care, the study found that children's contact with parents was associated with family image in children's mind and the feelings of joyfulness and happiness when they meet their parents. Family circumstances, care giving model and the distance between care giving facilities and the family are also factors affecting the contact between children and their parents and family members.

\section{Acknowledgements}

"This research is funded by Vietnam National University, Hanoi (VNU) under project number QG.16.41".

\section{Conflicts of Interest}

The authors declare no conflicts of interest regarding the publication of this paper.

\section{References}

[1] Gobind, T. (2013) Birth Family Contact and Placement Outcomes for Children in 
Kinship and Foster cAre. Canterbury University, Canterbury.

[2] Quinton, D., et al. (1997) Contact between Children Placed Away from Home and Their Birth Parents: Research Issues and Evidence. Clinical Child Psychology and Psychiatry, 2, 393-413. https://doi.org/10.1177/1359104597023007

[3] Bullen, T., Taplin, S., Kertesz, M., Humphreys, C. and McArthur, M. (2015) Literature Review on Supervised Contact between Children in Out-of-Home Care and Their Parents. Institute of Child Protection Studies, Canberra.

[4] (2016) National Assembly of the Socialist Republic of Vietnam, Luật trẻ em. Hà Nội.

[5] United Nations Convention on the Rights of the Child. 61 st Plenary Meeting, Committee on the Rights of the Child, New York. http://www.un.org/documents/ga/res/44/a44r025.htm

[6] UNICEF, Báo cáo phân tích tình hình trẻ em tại Việt Nam. http://www.un.org.vn/images/stories/pub_trans/SITAN_2010_vn.pdf

[7] Haight, W.L., Kagle, J.D. and Black, J.E. (2003) Understanding and Supporting Parent-Child Relationships during Foster Care Visits: Attachment Theory and Research. Social Work, 48, 195-207. https://doi.org/10.1093/sw/48.2.195

[8] Simsek, Z., et al. (2007) Prevalence and Predictors of Emotional and Behavioral Problems Reported by Teachers among Institutionally Reared Children and Adolescents in Turkish Orphanages Compared with Community Controls. Children and Youth Services Review, 29, 883-899.

https://doi.org/10.1016/j.childyouth.2007.01.004

[9] Sen, R. and Broadhurst, K. (2011) Contact between Children in Out-of-Home Placements and Their Family and Friends Networks: A Research Review. Child \& Family Social Work, 16, 298-309. https://doi.org/10.1111/j.1365-2206.2010.00741.x

[10] Salveron, M., Lewig, K. and Arney, F. (2009) Parenting Groups for Parents Whose Children Are in Care. Child Abuse Review, 18, 267-288. https://doi.org/10.1002/car.1070

[11] Salas Martínez, M.D., et al. (2016) Contact Visits between Foster Children and Their Birth Family: The Views of Foster Children, Foster Parents and Social Workers. Child \& Family Social Work, 21, 473-483. https://doi.org/10.1111/cfs.12163

[12] Leathers, S.J. (2003) Parental Visiting, Conflicting Allegiances, and Emotional and Behavioral Problems among Foster Children. Family Relations, 2, 53-63. https://doi.org/10.1111/j.1741-3729.2003.00053.x

[13] McWey, L.M., Acock, A. and Porter, B. (2010) The Impact of Continued Contact with Biological Parents upon the Mental Health of Children in Foster Care. Children and Youth Services Review, 32, 1338-1345. https://doi.org/10.1016/j.childyouth.2010.05.003

[14] Moyers, S., Farmer, E. and Lipscombe, J. (2006) Contact with Family Members and its Impact on Adolescents and Their Foster Placements. The British Journal of Social Work, 36, 541-559. https://doi.org/10.1093/bjsw/bch270

[15] John, T. (2010) Contact between Looked after Children and Their Parents: A Level Playing Field? Adoption \& Fostering, 34, 59-66. https://doi.org/10.1177/030857591003400311

[16] Atwool, N. (2013) Birth Family Contact for Children in Care: How Much? How Often? Who With? Child Care in Practice, 19, 181-198. https://doi.org/10.1080/13575279.2012.758086

[17] Helen, A., et al. (2013) Foster Carers and Family Contact: Foster Carers' Views of Social Work Support. Adoption \& Fostering, 37, 116-129. 
https://doi.org/10.1177/0308575913490273

[18] Mota, C.P. and Matos, P.M. (2015) Does Sibling Relationship Matter to Self-Concept and Resilience in Adolescents under Residential Care? Children and Youth Services Review, 56, 97-106. https://doi.org/10.1016/j.childyouth.2015.06.017

[19] Boéchat, H., Cantwell, N. and Dambach, M.C. (2009) Assessment of the Adoption System in Viet Nam-Final Report International Social Service (ISS). https://resourcecentre.savethechildren.net/node/5366/pdf/5366.pdf

[20] Anh, T.T.T., Liên, H.T.K. and Thảo, N.T.P. (2014) Rối nhiễu tâm lý ở nhóm trẻ mồ côi sống ở các trung tâm bảo trợ xã hội và nhóm trẻ sống cùng gia đình. In: Trong kỷ yếu hội thảo khoa học toàn quốc vế Sức khỏe tâm thẩn trong trường học. Thành Phố Hồ Chí Minh, Nhà xuất bản Đại học Quốc gia Hồ Chí Minh.

[21] Chính phủ Nước Cộng hòa Xã hội Chủ nghĩa Việt Nam (2017) Nghị định 56, Quy định chi tiết một số điều của Luật trẻ em, Chính phủ. In: Nội, H., Ed.

[22] Delfabbro, P.H., Barber, J.G. and Cooper, L. (2002) The Role of Parental Contact in Substitute Care. Journal of Social Service Research, 28, 19-39. https://doi.org/10.1300/J079v28n03_02

[23] Prasad, N. (2011) Decision Making Principles around Contact Visits: A Literature Review. UnitingCare Children, Young People and Families, Parramatta.

[24] Baker, A.J.L., Mehta, N. and Chong, J. (2013) Foster Children Caught in Loyalty Conflicts: Implications for Mental Health Treatment Providers. The American Journal of Family Therapy, 41, 363-375.

https://doi.org/10.1080/01926187.2012.728902

[25] Farmer, E.M.Z., et al. (2010) Enhancing "Usual Practice" Treatment Foster Care: Findings from a Randomized Trial on Improving Youths' Outcomes. Psychiatric Services, 61, 555-561. https://doi.org/10.1176/ps.2010.61.6.555

[26] Malet, M.F., et al. (2010) Young Children Returning Home from Care: The Birth Parents' Perspective. Child \& Family Social Work, 15, 77-86.

https://doi.org/10.1111/j.1365-2206.2009.00645.x 